\title{
INDEKS KUALITAS AIR DAN SEBARAN NUTRIEN SEKITAR BUDIDAYA LAUT TERINTEGRASI DI PERAIRAN TELUK EKAS, NUSA TENGGARA BARAT: ASPEK PENTING BUDIDAYA RUMPUT LAUT
}

\author{
I Nyoman Radiarta\# dan Erlania \\ Pusat Penelitian dan Pengembangan Perikanan Budidaya \\ (Naskah diterima: 5 Februari 2015; Revisi final: 9 Maret 2015; Disetujui publikasi: 11 Maret 2015)
}

\begin{abstract}
ABSTRAK
Kualitas perairan merupakan salah satu aspek penting dalam perikanan budidaya. Perubahan yang terjadi pada kondisi kimia atau fisik perairan dapat menyebabkan dampak negatif terhadap pertumbuhan biota budidaya. Data kualitas air hasil program pemantauan selama enam bulan di lokasi penelitian telah dianalisis untuk melihat kisaran indeks kualitas air dan sebaran nutrien yang terjadi di sekitar unit budidaya laut terintegrasi berbasis integrated multi-trophic aquaculture (IMTA) di Teluk Ekas Provinsi Nusa Tenggara Barat. Pengamatan dilakukan pada bulan Juni-November 2014, sebanyak 13 titik pengamatan yang disebar secara diagonal dengan pusat keramba jaring apung ikan laut. Seluruh data dianalisis secara spasial dan temporal. Hasil penelitian menunjukkan bahwa nilai indeks kualitas air di lokasi penelitian tergolong kategori sedang-baik. Bulan Juli merupakan bulan dengan nilai indeks yang baik dengan kategori sedang-sangat baik (50-83); sedangkan bulan September memiliki nilai indeks yang relatif rendah dengan kategori buruksedang (33-60). Berdasarkan sebaran nutrien (amonium, nitrat, dan orto-fosfat) menunjukkan fluktuasi secara spasial dan temporal. Konsentrasi nutrien umumnya tersedia dengan baik pada jarak $60 \mathrm{~m}$ dari KJA. Hasil penelitian ini dapat memberikan gambaran tentang kondisi kualitas perairan dan ketersediaan nutrien untuk mendukung pertumbuhan dan produktivitas budidaya rumput laut dengan sistem IMTA.
\end{abstract}

KATA KUNCI: indeks kualitas air, sebaran nutrien, budidaya laut terintegrasi, rumput laut, Teluk Ekas

ABSTRACT: Water quality index and distribution of nutrient around integrated marine aquaculture in Ekas Bay, West Nusa Tenggara: an important factor for seaweed aquaculture. By: I Nyoman Radiarta and Erlania

Water quality is one of the main concerns in aquaculture. Any change in the chemical or physical parameters can cause a negative effect on the growth of the organisms. Water quality data from six months monitoring program in the study area were analyzed to investigate the water quality index (WQI) and nutrient distribution occurring around the integrated multi-trophic aquaculture (IMTA) in Ekas Bay West Nusa Tenggara Province. Observations at 13 stations were made in June-November 2014. The stations were distributed diagonal with marine fish cage as a center. All data were analyzed spatially and temporally. The results showed that the WQI in the study area were classified medium-good categories. Temporal observation indicated that July had the highest index with category medium-very good (50-83) while September relatively had the lowest index with category bad-medium (33-60). Based on the distribution of nutrients (ammonium, nitrate, and ortho-phosphate) showed temporal and spatial fluctuations. Concentrations of nutrients were generally available with a distance of $60 \mathrm{~m}$ from the cage. The results of this study could provide an illustration of the water quality condition and the availability of nutrients in order to support growth and productivity of seaweed aquaculture system with integrated multi-trophic aquaculture (IMTA).

KEYWORDS: $\quad$ water quality index, nutrient distribution, integrated mariculture, seaweed, Ekas Bay

\# Korespondensi: Pusat Penelitian dan Pengembangan Perikanan Budidaya. Jl. Ragunan No. 20, Pasar Minggu, Jakarta Selatan 12540, Indonesia. Tel.: + (021) 7805051

E-mail: radiarta@yahoo.com 


\section{PENDAHULUAN}

Aktivitas budidaya laut dipengaruhi oleh beberapa aspek penting di antaranya kondisi kualitas perairan. Perubahan yang terjadi pada kondisi perairan yang meliputi: aspek fisik, kimia, dan nutrien dapat menyebabkan dampak negatif terhadap pertumbuhan biota budidaya, atau bahkan dapat menyebabkan kematian yang akhirnya berdampak pada menurunnya produksi. Indeks kualitas air (WQI) adalah sebuah nilai yang mengungkapkan kualitas air dengan menggabungkan beberapa hasil pengukuran parameter kualitas air (seperti oksigen terlarut, pH, nitrat, fosfat, amonia, klorida, kekerasan, logam, dan lain-lain). Pentingnya WQI untuk mengungkapkan komponen kualitas sumber air sudah lama dikenal dengan berbagai formulasi dan model yang digunakan (Bakan et al., 2010; Lumb et al., 2011; Poonam et al., 2013). Biasanya nilai indeks yang lebih tinggi menunjukkan kualitas air yang lebih baik dan nilai indeks yang rendah menunjukkan kualitas perairan yang buruk. Indeks ini menyediakan metode yang sederhana dan ringkas dalam menggambarkan kondisi kualitas air untuk berbagai keperluan seperti perikanan budidaya, rekreasi, air minum, dan irigasi.

Peningkatan produksi perikanan budidaya dapat dilakukan melalui perluasan lahan ataupun penerapan teknologi (inovasi) baru. Penerapan perikanan budidaya melalui penggunaan padat tebar spesies yang lebih tinggi atau penggunaan pakan yang besar dapat saja meningkatkan produksi. Namun, jika perkembangan ini tidak diatur secara baik, maka tentunya dampak negatif akan dirasakan baik terhadap lingkungan maupun keberlanjutan usaha budidayanya. Pengembangan perikanan budidaya yang berazaskan lingkungan (EAA/ecosystem approach to aquaculture) merupakan aspek penting yang perlu diperhatikan oleh pembudidaya ataupun pengambil kebijakan (Soto et al., 2008). EAA bukan merupakan hal yang baru, konsep ini sudah banyak diimplementasikan dalam aktivitas budidaya skala kecil. Namun dalam penerapan EAA untuk skala besar dan intensif, konsep ini menjadi lebih susah diterapkan, dan merupakan suatu tantangan dalam pelaksanaannya. Penerapan pengembangan perikanan budidaya agar dapat berkelanjutan tentunya harus terintegrasi dengan seluruh ekosistem yang ada (Soto et al., 2008; Holmer et al., 2008; FAO 2010).

Aktivitas budidaya ikan laut dengan keramba jaring apung (KJA) dapat menyebabkan pengkayaan nutrien di sekitar kawasan KJA tersebut. Sebaran nutrien tersebut dapat dimanfaatkan oleh komoditas budidaya lainnya, seperti rumput laut, yang dapat mengekstrak dissolved inorganic nutrients dan kekerangan yang dapat memanfaatkan particulate organic matter serta teripang, sehingga terjadi keseimbangan antara proses biologi dan kimia pada sistem yang berkembang (Neori et al., 2000; Barrington et al., 2009). Pola pengembangan sistem budidaya ini dikenal dengan budidaya terintegrasi atau integrated multi-trophic aquaculture (IMTA). IMTA dapat menjadi opsi pengembangan budidaya laut karena selain dapat meningkatkan produksi dari beberapa komoditas secara simultan juga dapat meminimalkan dampak negatif terhadap lingkungan perairan (Radiarta et al., 2014a; Yuniarsih et al., 2014). Konsep penerapan IMTA adalah dengan memperhatikan tingkat trofik dari komoditas yang dibudidayakan, sehingga aliran energi yang tersedia dalam unit IMTA tersebut dapat dimanfaatkan secara maksimal. Telaah tentang pelaksanaan budidaya laut secara terintegrasi telah dipublikasi oleh FAO (Soto, 2009). Secara umum publikasi tersebut melihat berbagai aplikasi budidaya secara terintegrasi (IMTA) di daerah sub-tropis (Barington et al., 2009), tropis (Troell, 2009), dan Laut Mediterranean (Angel \& Freeman, 2009). Penerapan IMTA di laut ini sangat sesuai dengan konsep EAA untuk budidaya laut (Costa-Pierce, 2008). Model IMTA ini dapat memadukan berbagai teknik budidaya dengan jarak tertentu dalam kawasan budidaya. Penerapan IMTA ini sangat fleksibel dan dapat diterapkan di perairan terbuka atau unit budidaya di daratan baik di perairan tawar maupun di laut, bahkan pengembangan IMTA ini juga sudah menyebar sampai pada lautan terbuka (Troell, 2009; Troell et al., 2009). Tujuan dari penelitian ini adalah untuk menganalisis indeks kualitas perairan dan pola sebaran nutrien sekitar unit IMTA di Teluk Ekas Provinsi Nusa Tenggara Barat. Analisis dilakukan secara spasial dan temporal. Hasil analisis ini diharapkan dapat memberikan gambaran tentang kondisi kualitas perairan di sekitar KJA dalam satu sistem IMTA sebagai salah satu aspek penting budidaya rumput laut yang berhubungan dengan penyebaran nutrien dan kondisi perairan untuk mendukung pertumbuhan dan tingkat produktivitas budidaya rumput laut.

\section{BAHAN DAN METODE}

\section{Lokasi Penelitian}

Penelitian dilaksanakan di Teluk Ekas Kabupaten Lombok Timur, Nusa Tenggara Barat (Gambar 1). Teluk Ekas dengan luasan mencapai 5.313 ha merupakan kawasan yang sangat potensial untuk pengembangan budidaya laut (Radiarta et al., 2003). Beberapa aktivitas budidaya yang telah berkembang di wilayah tersebut meliputi: budidaya rumput laut, budidaya ikan kerapu, dan budidaya lobster. Selain aktivitas budidaya laut, aktivitas penangkapan juga berkembang pesat terutama penangkapan benih lobster alam. 


\section{Model Budidaya Terintegrasi (IMTA) dan Pengumpulan Data}

Model IMTA yang dikembangkan dalam penelitian ini adalah kombinasi antara beberapa komoditas dengan tingkat tropik yang berbeda yaitu: ikan bawal bintang (Trachinotus Blochii, Lacepede), rumput laut (Kappaphycus alvarezii) dan abalon (Haliotis asinina). Unit keramba jaring apung (KJA) digunakan sebagai titik pusat dalam model IMTA ini (posisi: $116.45087^{\circ}$ BT; $-8.87341^{\circ}$ LS), sedangkan unit rumput laut dipasang diagonal pada empat titik: E2, E4, E6 dan E8 (Gambar 1). Ikan bawal bintang dibudidayakan pada KJA yang terdiri atas empat jaring berukuran $3 \mathrm{~m} \mathrm{x}$ $3 \mathrm{~m}$ x $3 \mathrm{~m}$, dan diletakkan pada kedalaman perairan sekitar $14 \mathrm{~m}$. Setiap jaring diisi sebanyak 500 ekor dengan ukuran awal ikan adalah sekitar 3-4 cm (3-5 gram). Budidaya ikan bawal bintang pada sistem IMTA ini dilakukan selama 150 hari (5 bulan); setelah satu bulan pemeliharaan dilakukan grading berdasarkan ukuran ikan; sehingga pada akhir penelitian diperoleh empat grade ukuran ikan yang berbeda yang ditempatkan pada setiap jaring KJA. Pakan yang digunakan dalam penelitian ini adalah pakan pelet komersial. Pakan diberikan dua kali sehari yaitu pagi dan sore hari dengan ukuran pelet sesuai dengan ukuran ikan yang dibudidayakan. Pemberian pakan pada dilakukan dengan feeding rate 3-7\% dari biomassa ikan. Rumput laut dibudidayakan dengan sistem rakit dengan ukuran masing-masing $7 \mathrm{~m} \mathrm{x} 7 \mathrm{~m}$. Satu unit rakit terdiri atas 35 bentangan tali ris dan setiap tali ris terdiri atas 35 titik tanam/ikatan rumput laut, dengan jarak tanam sekitar $20 \mathrm{~cm}$. Setiap titik tanam dipasang bibit rumput laut awal dengan bobot sekitar 50 gram. Total berat bibit/unit rumput laut mencapai sekitar $61 \mathrm{~kg}$.

Pengumpulan data kualitas perairan dilakukan selama enam bulan program pemantauan yaitu bulan Juni-November 2014. Sebanyak 13 titik pengamatan kualitas perairan disebar di sekitar unit IMTA. Titik pengamatan tersebut didesain melingkar dengan jarak lingkaran pertama $60 \mathrm{~m}$ dan jarak lingkaran kedua 150 $\mathrm{m}$, dengan titik pusat berada di KJA unit IMTA (Gambar 1). Parameter kualitas perairan yang dikumpulkan meliputi parameter fisik, kimia, dan kesuburan perairan, dan diukur pada permukaan perairan $(<1 \mathrm{~m})$. Pengukuran kualitas air dilakukan pada kisaran waktu 10:00-16:00 waktu setempat. Waktu pengamatan ini dapat mewakili kondisi pasang dan surut di lokasi penelitian. Parameter diukur langsung di lapangan menggunakan YSI profesional+ meliputi: suhu, salinitas, oksigen (dissolved oxygen/DO), dan $\mathrm{pH}$. Selain pengukuran di lapangan, contoh air diambil untuk dianalisis di Laboratorium Air Biotrop Bogor. Metode pengambilan, preservasi, dan analisis contoh air mengacu pada metode standar APHA (2005). Parameter yang dianalisis meliputi: kekeruhan, total fosfat (TP), orto-fosfat $\left(\mathrm{PO}_{4}^{-}-\mathrm{P}\right)$, nitrat $\left(\mathrm{NO}_{3}-\mathrm{N}\right)$, dan amonium $\left(\mathrm{NH}_{4}-\mathrm{N}\right)$.

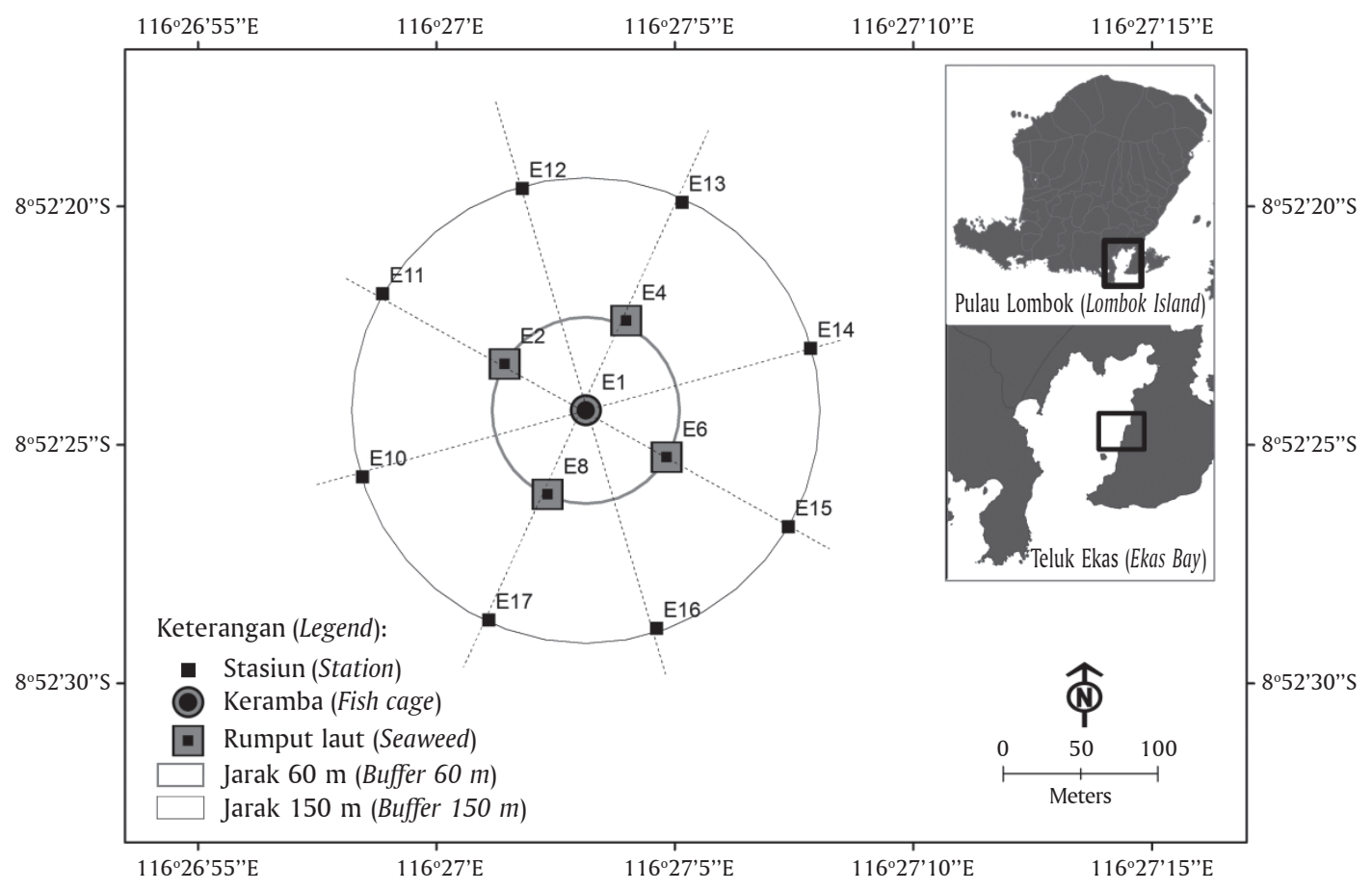

Gambar 1. Lokasi penelitian di Teluk Ekas Kabupaten Lombok Timur, NTB dan model pengembangan budidaya terintegrasi (IMTA). E1-E17 merupakan titik pengamatan kualitas perairan

Figure 1. The study area in Ekas Bay East Lombok Regency, NTB and development of integrated multitrophic aquaculture model. E1-E17 indicate the water quality sampling stations 


\section{Analisis Data}

Pada penelitian ini, data kualitas air dianalisis dengan menghitung indeks kualitas air dan sebaran spasial. Selain itu, karakteristik kondisi kualitas air yang dikumpulkan selama penelitian juga dianalisis secara statistik deskriptif (meliputi: minimum, maksimum, rataan, dan standar deviasi).

Indeks kualitas air (water quality index/WQI) adalah pendekatan matematika yang digunakan untuk mengubah beberapa parameter data kualitas perairan menjadi satu besaran yang merangkum parameter kualitas yang berbeda. WQI adalah indeks kualitas air untuk penggunaan tertentu, seperti misalnya melihat kelayakannya bagi budidaya laut. Pada penelitian ini, WQI dihitung berdasarkan tiga parameter yaitu DO, kekeruhan, dan total fosfat, yang dikenal dengan indeks minimal $\left(\mathrm{WQI}_{\text {min }}\right)$. Tiga parameter yang digunakan ini merupakan parameter kunci yang mewakili karakteristik fisik, kimia, dan nutrien perairan yang dapat berfluktuasi dan memengaruhi perkembangan biota budidaya (SimÕes et al., 2008). Penggunaan WQI dalam penelitian ini digunakan untuk melihat kondisi kualitas perairan secara umum, melalui pemberian skor pada perairan yang menunjukkan kualitasnya (Bakan et al., 2010). WQI dihitung dengan menggunakan persamaan berikut (SimÕes et al., 2008):

$$
\mathrm{WQI}_{\min }=\frac{\mathrm{CDO}+\mathrm{CTurb}+\mathrm{CTotP}}{3}
$$

di mana:

$\mathrm{CDO}=$ Nilai DO setelah normalisasi

CTurb $=$ Nilai kekeruhan setelah normalisasi

CTotP $=$ Nilai total fosfat setelah normalisasi

Normalisasi dari ketiga parameter kualitas air ditampilkan pada Tabel 1 (Pesce \& Wunderlin, 2000; SimÕes et al., 2008). Klasifikasi WQI dibagi menjadi lima kelas yaitu: sangat baik $(>80-100)$, baik $(>60$ 80 ), sedang ( $>40-60)$, buruk $(>20-40)$, dan sangat buruk (>0-20) (Fulazzaky et al., 2010).
Sebaran kesuburan perairan seperti orto-fosfat $\left(\mathrm{PO}_{4}-\mathrm{P}\right)$, nitrat $\left(\mathrm{NO}_{3}-\mathrm{N}\right)$, dan amonium $\left(\mathrm{NH}_{4}-\mathrm{N}\right)$ di sekitar unit IMTA dianalisis secara spasial dengan metode interpolasi inverse distance weighted (IDW) (Johnson \& McChow, 2001). Analisis spasial dilakukan dengan menggunakan ArcGIS v.10 (The Environmental System Research Institute (ESRI), USA).

\section{HASIL DAN BAHASAN}

\section{Kondisi Umum Teluk Ekas}

Teluk Ekas terletak di bagian selatan Pulau Lombok yang membujur dari barat ke timur diantara $116^{\circ} 23^{\prime}$ $116^{\circ} 29^{\prime}$ Bujur Timur dan $8^{\circ} 49^{\prime}-8^{\circ} 55^{\prime}$ Lintang Selatan. Teluk Ekas dengan luasan 5.313 ha dan panjang garis pantai mencapai $44 \mathrm{~km}$ merupakan kawasan teluk yang masuk dalam dua kabupaten yaitu Kabupaten Lombok Tengah (Desa Awang) dan Kabupaten Lombok Timur (Desa Pamongkong, Desa Sukaraja, dan Desa Batunampar). Teluk ini sangat berpotensi untuk pengembangan budidaya laut karena memiliki karakteristik pantai yang relatif tenang, terlindung, dan banyaknya goba (lagoon). Teluk Ekas telah ditetapkan dalam program PIJAR (sapi jagung rumput laut) Provinsi Nusa Tenggara Barat sebagai kawasan pengembangan minapolitan rumput laut (Anonimous, 2012). Produksi rumput laut di Teluk Ekas mengalami peningkatan yang signifikan dari 25.000 ton di tahun 2009 menjadi 59.108 ton di tahun 2011 (Anonimous, 2012). Selain program daerah, kawasan Teluk Ekas yang terletak di Lombok Timur ini juga telah dijadikan lokasi percontohan pengembangan program blue economy Kementerian Kelautan dan Perikanan (KKP, 2014).

Teluk Ekas sangat dipengaruhi oleh pola pasang surut harian dengan pola campuran yang cenderung ke harian ganda (Nontji, 1993). Kondisi pasang surut ini sangat memengaruhi luasan area yang dapat digunakan untuk budidaya laut. Pada saat surut terendah luasan teluk yang berpotensi untuk budidaya laut hanya sekitar 3.396 ha (64\% dari total luasan teluk), sisanya $36 \%$ berupa daerah kering yang ditumbuhi oleh padang

Tabel 1. Faktor normalisasi untuk menghitung $\mathrm{WQI}_{\text {min }}$

Table 1. Normalization factors for the $W Q I_{\min }$ calculation

\begin{tabular}{|c|c|c|c|c|c|c|c|c|c|c|c|}
\hline \multirow{2}{*}{$\begin{array}{c}\text { Peubah } \\
\text { Parameter }\end{array}$} & \multicolumn{11}{|c|}{ Faktor normalisasi (Normalization factors) } \\
\hline & 100 & 90 & 80 & 70 & 60 & 50 & 40 & 30 & 20 & 10 & 0 \\
\hline $\begin{array}{l}\text { Oksigen terlarut } \\
\text { Dissolved oxygen }(\mathrm{mg} / \mathrm{L})\end{array}$ & 87.5 & 87 & 86.5 & 86 & 85 & 84 & 83.5 & 83 & 82 & 81 & $<1$ \\
\hline $\begin{array}{l}\text { Total fosfat } \\
\text { Total phosphate (mg/L) }\end{array}$ & $<0.05$ & $<0.05$ & $<0.05$ & $<0.1$ & $<0.1$ & $<0.15$ & $<0.15$ & $<0.2$ & $<0.2$ & $<0.3$ & $<0.3$ \\
\hline $\begin{array}{l}\text { Kekeruhan } \\
\text { Turbidity (NTU) }\end{array}$ & $<5$ & $<10$ & $<15$ & $<20$ & $<25$ & $<30$ & $<40$ & $<60$ & $<80$ & 7100 & $>100$ \\
\hline
\end{tabular}


lamun, rumput laut alam, dan pecahan karang batu (Radiarta et al., 2003). Kondisi arus di dalam teluk umumnya dipengaruhi oleh pergerakan pasang surut dengan kecepatan antara 1-18 m/menit (Radiarta et al., 2003).

Kegiatan budidaya laut sudah cukup berkembang di Teluk Ekas, terbukti dengan banyaknya aktivitas budidaya yang dilakukan oleh masyarakat pesisir sekitar Dusun Ekas, Dusun Ujung, Dusun Saung, dan Dusun Batunampar. Budidaya laut yang banyak ditemukan adalah budidaya rumput laut, budidaya ikan, dan budidaya lobster. Selain kegiatan budidaya kawasan teluk ini mempunyai stok sumberdaya benih lobster yang cukup berlimpah. Belakangan ini dengan meningkatnya harga benih lobster (berkisar antara Rp. 12.000-17.000/ekor), telah menyebabkan banyaknya aktivitas penangkapan benih lobster alam.

\section{Kondisi Kualitas Perairan}

Pengembangan budidaya laut sangat dipengaruhi oleh kondisi lingkungan perairan. Kondisi lingkungan yang baik akan mendukung pertumbuhan komoditas yang dibudidayakan, dan sebaliknya. Tabel 2 menyajikan hasil pengukuran beberapa parameter penting kualitas perairan di 13 lokasi selama enam bulan program pemantauan (Juni-November 2014) di Teluk Ekas, Lombok Timur.

Suhu perairan selama penelitian menunjukkan fluktuasi dengan kisaran $26,3^{\circ} \mathrm{C}-30,9^{\circ} \mathrm{C}$ (Tabel 2). Suhu permukaan terendah ditemukan pada bulan September yaitu $26,30^{\circ} \mathrm{C}$, sedangkan suhu permukaan maksimum terukur pada bulan November mencapai $30,90^{\circ} \mathrm{C}$. Terjadinya peningkatan suhu ini sangat berpengaruh terhadap aktivitas budidaya rumput laut di lokasi penelitian. Budidaya rumput laut pada unit IMTA mengalami penurunan pertumbuhan dan bahkan mengalami kerusakan (gagal panen) sejak akhir bulan September, di mana suhu perairan melebihi $29^{\circ} \mathrm{C}$ dan memiliki tren yang terus meningkat (data tidak dipublikasi). Selain suhu, parameter lainnya seperti salinitas yang cukup tinggi dan nutrien sangat memengaruhi pertumbuhan rumput laut. Suhu ideal untuk budidaya rumput laut adalah berkisar antara $26^{\circ} \mathrm{C}-29^{\circ} \mathrm{C}$ (Parenrengi et al., 2011; Pong-Masak et al., 2012). Sedangkan sesuai dengan baku mutu air laut untuk biota laut mensyaratkan suhu berkisar antara $28^{\circ} \mathrm{C}-32^{\circ} \mathrm{C}$ (KLH, 2004).

Kandungan oksigen terlarut (DO) sangat penting diperhatikan dalam penelitian ini, khususnya untuk komoditas ikan bawal bintang dan abalon. Kisaran DO permukaan yang terukur selama waktu penelitian antara 3,1-11,4 mg/L (Tabel 2). Kisaran DO di lokasi penelitian masih menunjukkan nilai yang baik untuk mendukung perkembangan komoditas budidaya. Kisaran DO yang ideal untuk ikan bawal bintang adalah 7-9 mg/L (Anonimous, 2013), sedangkan untuk abalon adalah $>4 \mathrm{mg} / \mathrm{L}$ (Priyambodo et al., 2012). Menurut Stickney (2009), kandungan oksigen terlarut yang diinginkan dalam sistem akuakultur adalah sekitar 5 $\mathrm{mg} / \mathrm{L}$; sedangkan konsentrasi oksigen terlarut $<3 \mathrm{mg} /$ L menjadi pembatas bagi kebanyakan organisme akuatik. Effendi (2003) juga menyatakan bahwa hanya sedikit jenis ikan yang dapat bertahan pada kondisi oksigen terlarut $<3 \mathrm{mg} / \mathrm{L}$ dengan masa pemaparan yang singkat. Jumlah oksigen terlarut di dalam air pada kondisi saturasi dipengaruhi oleh tiga faktor utama yaitu: suhu, salinitas, dan ketinggian perairan dari permukaan laut (altitude); semakin tinggi suhu, salinitas, dan altitude maka kelarutan oksigen akan semakin berkurang (Stickney, 2009; Effendi, 2003). Selain itu, kadar oksigen terlarut juga berfluktuasi secara harian dan musiman tergantung pada percampuran (mixing) dan pergerakan (turbulence) massa air, aktivitas fotosintesis, respirasi, dan limbah (effluent ) yang masuk ke badan air (Effendi, 2003).

Pengukuran terhadap salinitas perairan menunjukkan nilai yang masih baik untuk komoditas budidaya dengan kisaran 30,0-38,0 ppt (Tabel 2). Salinitas yang sesuai untuk pertumbuhan rumput laut berkisar 28$35 \mathrm{ppt}$, namun untuk mendukung pertumbuhan rumput laut, nilai salinitas 32-35 ppt merupakan nilai ideal (Parenrengi et al., 2011). Kondisi pH perairan di lokasi IMTA masih baik untuk budidaya laut. Kisaran pH yang diperoleh adalah 7,5-8,4 (Tabel 2). Kondisi pH perairan ini tidak terlalu berfluktuasi, dan sesuai dengan persyaratan pH untuk biota laut (KLH, 2004).

Kondisi kekeruhan perairan berkisar antara 0,325,4 NTU (Tabel 2). Tingkat kekeruhan perairan ini berhubungan terbalik dengan tingkat kecerahan di lokasi penelitian. Tingkat kekeruhan < 5 NTU merupakan baku mutu air laut untuk biota laut (KLH, 2004). Kekeruhan ini terkait dengan kemampuan sinar matahari masuk dalam kolom air yang dibutuhkan untuk proses fotosintesis pada tumbuhan air. Adanya unit KJA ikan dapat merupakan menyebabkan tingginya tingkat kekeruhan di sekitar unit IMTA. Kekeruhan yang terjadi tersebut dapat disebabkan oleh karena tingginya kandungan nutrien yang mendukung pertumbuhan plankton ataupun kandungan partikel sedimen/lumpur. Kekeruhan yang terjadi di sekitar pesisir dapat disebabkan oleh tingginya kandungan lumpur yang dapat berasal dari aliran sungai ataupun aktivitas pemukiman sekitar kawasan pantai. Air yang berlumpur dapat menghalangi masuknya cahaya ke dalam kolom air sehingga menghambat pertumbuhan rumput laut yang menyebabkan thalus membusuk sehingga mudah patah. 


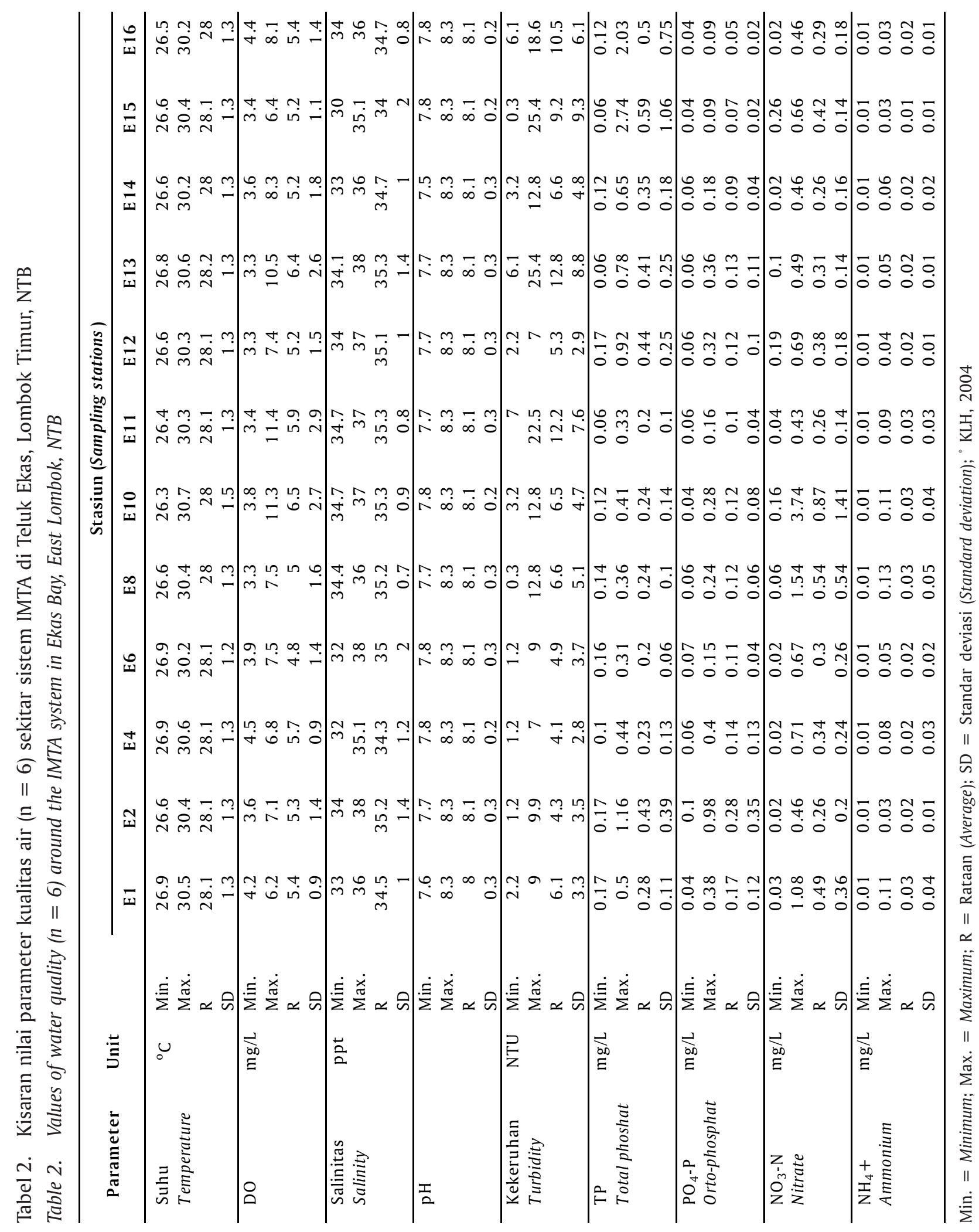




\section{Indeks Kualitas Perairan}

WQI yang dianalisis dalam penelitian ini merefleksikan kondisi kualitas perairan, karena menggunakan tiga parameter penting yaitu: DO, kekeruhan, dan total fosfat, yang dikenal dengan indeks minimal $\left(\mathrm{WQI}_{\text {min }}\right)$. Penggunaan tiga parameter tersebut sangat efektif dan dapat digunakan sebagai indikator kegiatan perikanan budidaya terhadap lingkungan perairan (SimÕes et al., 2008). Berbagai jenis WQI yang telah diperkenalkan untuk mengkaji kondisi kualitas perairan (Poonam et al., 2013), namun indeks minimal (WQI ${ }_{\text {min }}$ ) sangat efektif dan efisien untuk mengkaji kondisi kualitas perairan (SimÕes et al., 2008; Bakan et al., 2010).

Hasil analisis $\mathrm{WQI}_{\min }$ menunjukkan bahwa kondisi perairan di 13 stasiun selama enam bulan program pemantauan masuk dalam kategori sedang-baik (Gambar 2). Nilai indeks yang diperoleh cukup berfluktuasi berdasarkan waktu pemantuan di 13 stasiun pengamatan. Berdasarkan perbedaan waktu, nilai indek yang terbaik ditemukan pada bulan Juli, dan ditemukan hampir di semua stasiun pengamatan dengan kisaran nilai WQI antara 50-83 (rata-rata 66). Hal ini menunjukkan bahwa pada bulan tersebut mempunyai kondisi perairan yang sangat baik untuk mendukung pertumbuhan biota yang dibudidayakan. Sebaliknya, pada bulan September, kondisi perairan kurang baik yang ditandai dengan nilai $W Q I_{\text {min }}$ yang relatif rendah dengan kisaran 33-60 (rata-rata 48). Kondisi ini sangat mempengaruhi produktivitas budidaya laut yang ada pada unit IMTA. Hasil pengamatan budidaya rumput laut pada bulan Juli menunjukkan peningkatan pertumbuhan sampai pada hari ke-45 dengan rata-rata bobot akhir 77,2 gram/ titik tanam; sedangkan pada bulan September terjadi penurunan pertumbuhan dari hari ke-30 ke hari ke45 , dengan rata-rata bobot akhir 20,6 gram/titik tanam (Radiarta et al., 2014b). Berdasarkan kisaran nilai WQI ${ }_{\text {min }}$ yang diperoleh selama enam bulan pengamatan di 13 stasiun menunjukkan bahwa pada bulan Juli, tiga parameter kualitas perairan (DO, kekeruhan, dan total fosfat) yang diamati masuk dalam kisaran yang ideal untuk aktivitas budidaya laut (KLH, 2004). Sedangkan pada bulan September, parameter total fosfat menunjukkan kisaran nilai yang cukup tinggi yang ditemukan hampir di semua stasiun pengamatan dengan kisaran antara 0,12-2,74 mg/L. Kondisi ini dapat menyebabkan turunnya kualitas lingkungan perairan. Tingginya kandungan total fosfat dalam perairan dapat menyebabkan terjadinya kelimpahan alga yang berlebihan (algae bloom; Effendi, 2003; Nontji, 2008). Alga yang berlimpah ini dapat membentuk lapisan pada permukaan air, yang selanjutnya dapat menghambat penetrasi oksigen dan cahaya matahari, sehingga kurang menguntungkan bagi eksosistem perairan, dan dapat mempengaruhi aktivitas budidaya laut dalam kawasan tersebut. Masalah serius pada kondisi alga bloom adalah fluktuasi oksigen yang tinggi di mana produksi oksigen tinggi pada siang hari (fotosintesa) dan konsumsi oksigen tinggi (respirasi) pada malam hari sehingga terjadi deplesi oksigen dan kritis bagi biota perairan.

\section{Sebaran Nutrien Sekitar Unit IMTA}

Pemberian pakan pada ikan bawal bintang tidak sepenuhnya dapat dimanfaatkan oleh ikan tersebut. Ada bagian yang terbuang ke perairan yang berasal

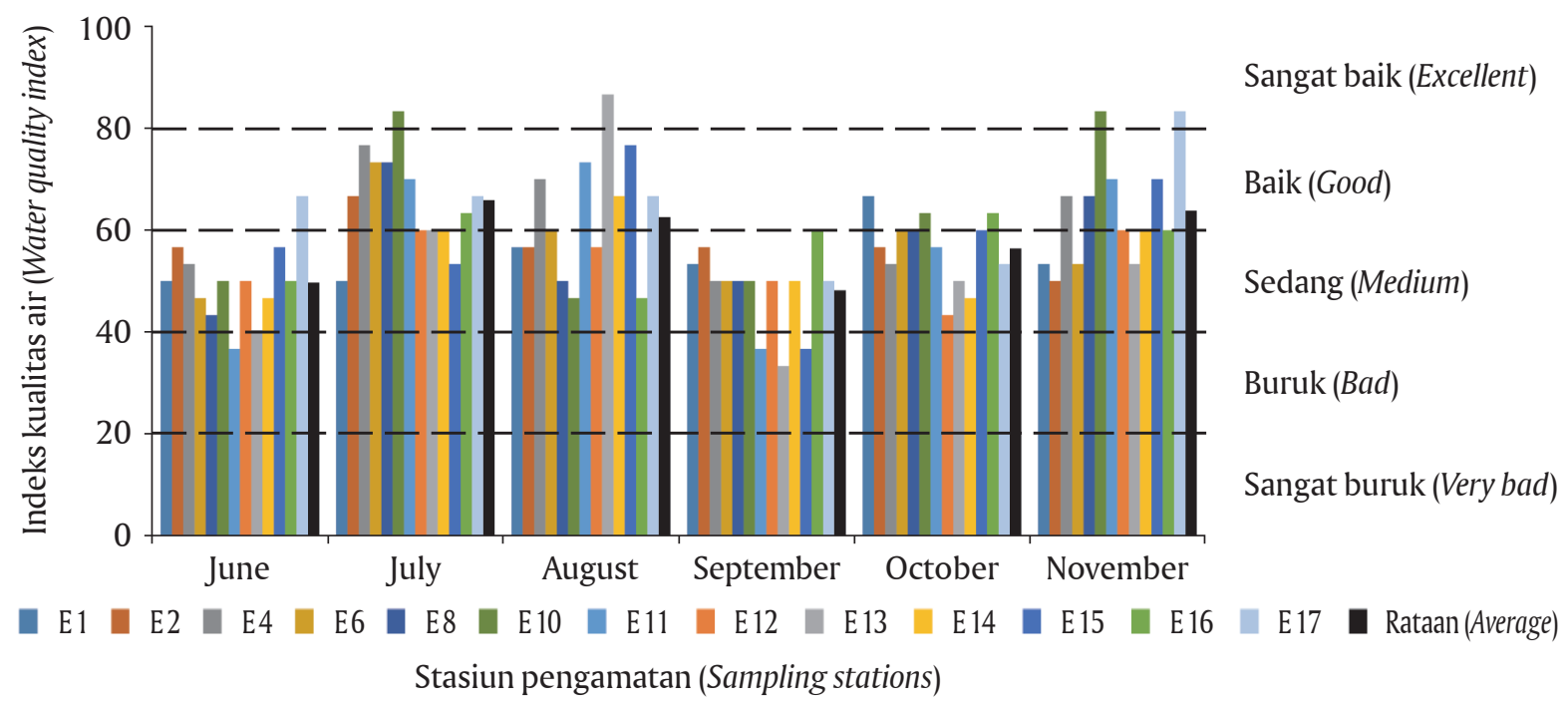

Gambar 2. Indeks kualitas perairan selama enam bulan pemantauan sekitar sistem IMTA di Teluk Ekas, Nusa Tenggara Barat. Sisi kanan menunjukkan pembagian kriteria indeks kualitas air

Figure 2. Water quality index during six months monitoring program around the IMTA system in Ekas Bay, West Nusa Tenggara. Right side indicates the criteria of water quality index 
dari sisa pakan yang tidak termakan ataupun sisa hasil metabolisme ikan (ekskresi ikan). Menurut Sanderson et al. (2008) sekitar 70\% nitrogen (N) dan $80 \%$ fosfat $(\mathrm{P})$ yang diberikan pada budidaya ikan salmon akan terlepas ke lingkungan perairan berupa buangan sisa pakan, proses metabolisme, feses, dan respirasi. Selanjutnya dilaporkan Wang et al. (2012) bahwa dari total input pakan yang diberikan, sekitar $70 \%$, 62\%, dan 70\% dari total karbon, nitrogen dan fosfat akan hilang ke perairan. Penelitian yang dilakukan Rachmansyah et al. (2003) menyimpulkan bahwa beban nutrien dari KJA ikan bandeng yang terbuang ke lingkungan perairan masing-masing mencapai 43,56 kg nitrogen (N); 31,00 kg fosfor (P); dan 148,41 kg karbon/ton produksi ikan. Ketersediaan nutrien di perairan yang berasal dari KJA ikan laut dapat dimanfaatkan oleh rumput laut. Melalui aktivitas budidaya rumput laut di sekitar KJA ikan secara simultan dapat memanfaatkan ketersediaan nutrien dan mengurangi terjadinya pengkayaan nutrien perairan yang berakibat pada terjadinya eutrofikasi (Reid et al., 2013; Radiarta et al., 2014). Pemanfaatan rumput laut (Ulva) pada budidaya terintegrasi dengan ikan dapat mereduksi limbah nutrien sebesar $<30 \%$ dari total input sebesar $2.271 \mathrm{~g} \mathrm{~N} /$ tahun (Neori et al., 2000).

Di kawasan pesisir, komposisi nutrien yang terpenting bagi pertumbuhan tanaman air (rumput laut) adalah nitrogen dan fosfat. Konsentrasi kedua parameter ini secara alami sangat kecil, sehingga sering kali menjadi faktor pembatas bagi pertumbuhan rumput laut. Ketersediaan nutrien pada air laut memberikan pengaruh yang sangat besar terhadap keberadaan tumbuhan akuatik, termasuk rumput laut. Senyawa nitrogen yang umumnya ditemukan pada air laut adalah $\mathrm{NO}_{3}, \mathrm{NO}_{2}$, dan $\mathrm{NH}_{3}$ yang konsentrasinya semakin menurun dengan bertambahnya kedalaman perairan; pada alga merah makroskopik ditunjukkan bahwa terdapatnya hubungan antara laju pertumbuhan dengan bentuk dan konsentrasi senyawa nitrogen (Dawes, 1981).

Sebaran nutrien (amonium, nitrat, dan ortofosfat) pada permukaan perairan di sekitar kawasan IMTA di sajikan pada Gambar 3 dan Tabel 2. Secara umum, pola sebaran spasial nutrien di lokasi penelitian memiliki pola yang bervariasi pada setiap bulan pengamatan. Pada bulan Juni-Juli sangat jelas terlihat sebaran dari utara-selatan; bulan Agustus lebih terkonsentrasi di tengah dan memiliki kecenderungan menyebar timurbarat. Sedangkan bulan September-November, pola sebaran memiliki kecenderungan tenggara-barat laut. Terjadinya variasi sebaran nutrien ini dapat disebabkan oleh kecepatan dan arah arus ataupun angin yang terjadi di lokasi penelitian. Hasil penelitian Manoppo et al. (2014) menunjukkan kecepatan dan arah arus di sekitar pulau lombok cukup bervariasi, dan memiliki pola arah yang serupa dengan sebaran nutrien yang terjadi di lokasi penelitian. Hasil kajian Radiarta et al. (2003) menunjukkan bahwa kondisi arus di Teluk Ekas umumnya dipengaruhi oleh pergerakan pasang surut dengan kecepatan antara 1-18 m/menit.

Sebaran amonium $\left(\mathrm{NH}_{4}+\right)$ di sekitar kawasan IMTA menunjukkan fluktuasi dari bulan Juni-November. Konsentrasi terkecil amonium yaitu 0,009 mg/L ditemukan pada bulan Oktober-November, sedangkan konsentrasi terbesar mencapai $0,127 \mathrm{mg} / \mathrm{L}$ ditemukan pada bulan Agustus. Sebaran amonium ini umumnya terkonsentrasi antara jarak 60-150 m dari KJA ikan (Gambar 3A). Pola serupa juga ditemukan oleh Sanderson et al. (2008), bahwa konsentrasi amonium terbesar ditemukan dekat dengan KJA ikan salmon (pada jarak $<50 \mathrm{~m}$ ) dengan nilai maksimal sekitar 8 $\mathrm{mM}$.

Distribusi nitrat secara spasial menunjukkan adanya fluktuasi secara temporal dan spasial (Gambar 3B). Konsentrasi nitrat tertinggi $(3,739 \mathrm{mg} / \mathrm{L})$ ditemukan pada bulan Agustus, sedangkan yang terendah $(0,01$ mg/L) pada bulan September. Kisaran konsentrasi nitrat yang tinggi umumnya juga tersebar secara berfluktuasi pada jarak antara 0-160 m. Liu et al. (2013) melakukan penajaman analisis tentang kesesuaian lahan budidaya rumput laut (Saccharina japonica), dengan memasukkan parameter nitrat. Hasil yang diperoleh menunjukkan bahwa hanya sekitar 64,4\% lokasi di Teluk Funka sesuai untuk budidaya rumput laut, dan hasil tersebut sangat sesuai dengan kondisi di lapangan. Ketersediaan nitrat di perairan pada lokasi yang berbeda juga memberikan tingkat pertumbuhan rumput laut yang berbeda. Kotiya et al. (2011) membandingkan tingkat pertumbuhan rumput laut (Kappaphycus alvarezii) di sembilan lokasi yang berbeda, dan menunjukkan bahwa pada musim panas, lokasi dengan konsentrasi nitrat tertinggi (19,2 mg/ L) memiliki pertumbuhan rumput laut yang baik $(22,36$ $\mathrm{kg})$. Penelitian terhadap salah satu spesies chlorophyta yaitu Codium fragile, menunjukkan pertumbuhan yang sama baiknya dengan sumber nitrogen dalam bentuk $\mathrm{NO}_{2}{ }^{-}$dengan $\mathrm{NO}_{3}{ }^{-}$maupun $\mathrm{NH}_{4}{ }^{+}$; sedangkan Goniotrichum elegans dan Nemalion multifidum dapat tumbuh lebih baik dengan sumber nitrogen dalam bentuk $\mathrm{NO}_{2}$ dibandingkan $\mathrm{NO}_{3}^{-}$(Hanisak, 1983). Nilai baku mutu kandungan nitrat perairan untuk biota laut berdasarkan KEPMENLH No. 51 Tahun 2004 adalah 0,008 mg/L (KLH, 2004).

Fosfat merupakan bentuk fosfor yang dapat dimanfaatkan oleh tumbuhan yang merupakan unsur esensial bagi alga (Effendi, 2003). Tumbuhan akuatik umumnya memanfaatkan orto-fosfat sebagai sumber 
fosfor (Effendi 2003, Dawes 1981). Effendi (2003) juga menyatakan bahwa pada saat perairan mengandung fosfor dalam jumlah cukup, alga akan mengakumulasi fosfor di dalam sel melebihi kebutuhannya (luxury consumption), dan kelebihan tersebut akan dimanfaatkan pada saat perairan mengalami defisiensi fosfor sehingga alga masih dapat tumbuh selama beberapa waktu. Namun pada perairan laut, biasanya fosfor bukan merupakan faktor pembatas pertumbuhan.
Sebaran spasial orto-fosfat permukaan perairan di lokasi penelitian berfluktuasi dengan konsentrasi umumnya menyebar merata dari KJA ikan laut sampai pada jarak $160 \mathrm{~m}$ (Gambar 3C). Konsentrasi orto-fosfat terbesar ditemukan pada bulan September $(0,979$ $\mathrm{mg} / \mathrm{L})$, dan konsentrasi terendah bulan Agustus-November $(0,04 \mathrm{mg} / \mathrm{L})$. Nilai baku mutu kandungan fosfat perairan untuk biota laut berdasarkan KEPMENLH No. 51 Tahun 2004 adalah $0,015 \mathrm{mg} / \mathrm{L}(\mathrm{KLH}, 2004)$.
(A) Amonium - $\mathrm{NH}_{4}+(\mathrm{mg} / \mathrm{L})$

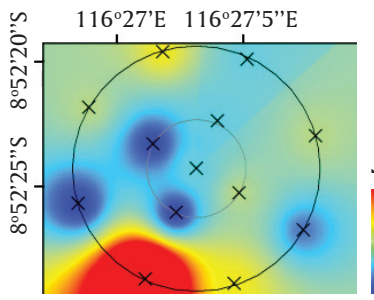

Jun

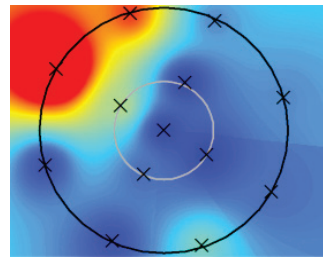

Jul

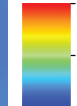

0.049

0.010
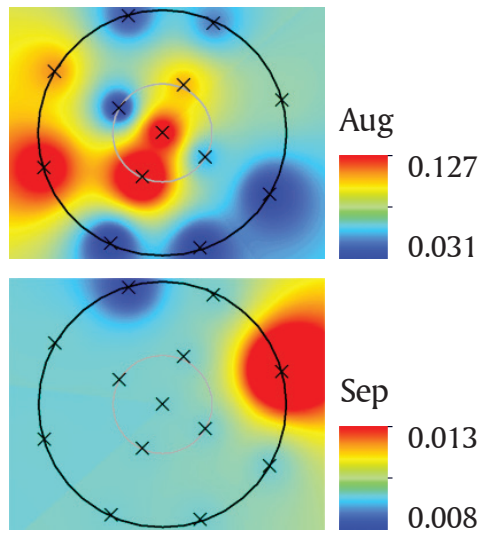

0.013

0.008
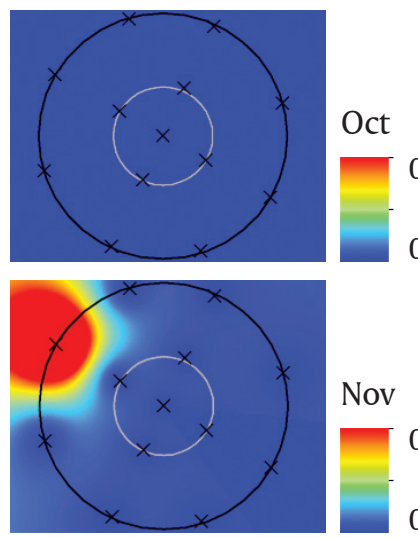

0.009

$\mathrm{x}=$ Stasiun pengamatan (Sampling stations)
(B) Nitrat - $\mathrm{NO}_{3}-\mathrm{N}(\mathrm{mg} / \mathrm{L})$

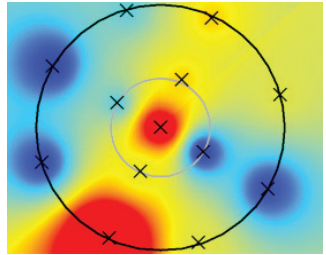

Jun
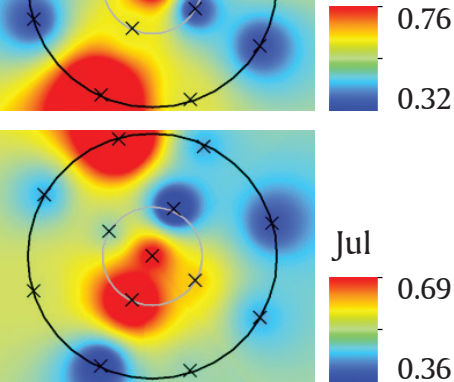

Jul
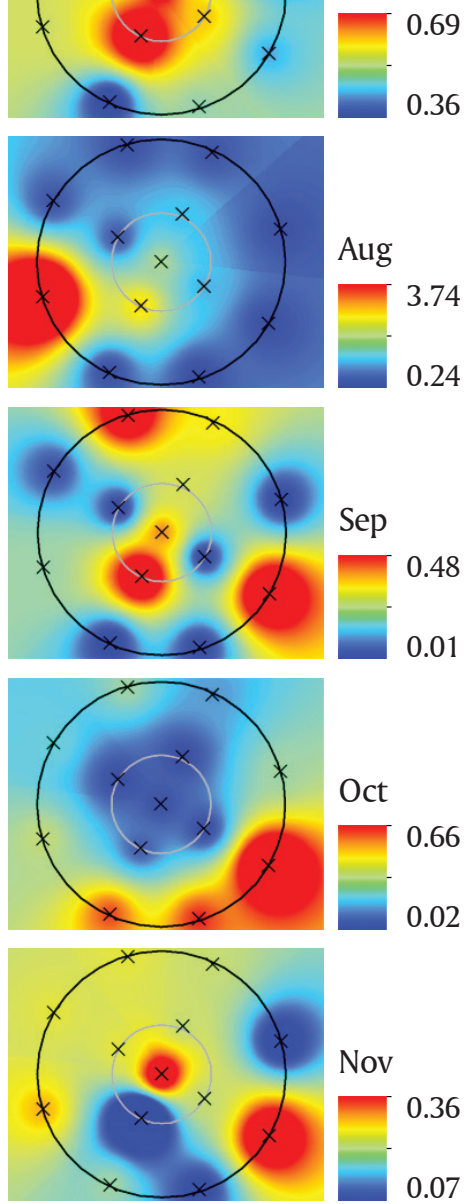

Nov

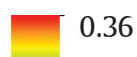

0.07

\section{南}

(C) Orto-fosfat - $\mathrm{PO}_{4}-\mathrm{P}(\mathrm{mg} / \mathrm{L})$
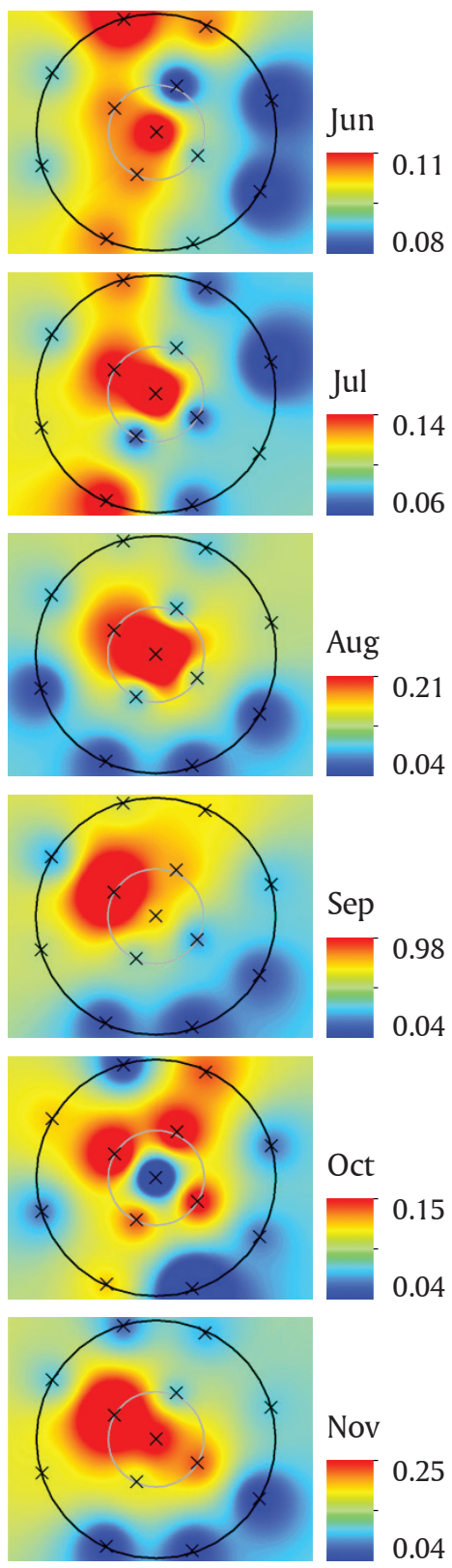

雷 $\begin{array}{ccc}0 & 100 \quad 200 \text { Meters }\end{array}$

Gambar 3. Distribusi spasial nutrien di permukaan perairan sekitar sistem IMTA di Teluk Ekas, Lombok Timur, NTB

Figure 3. Spatial distribution of nutrient at the surface water around the IMTA system in Ekas Bay, East Lombok, NTB 
Penelitian tentang distribusi nutrien sekitar KJA ikan laut sudah banyak dilakukan (Parello et al., 2005; Wang et al., 2012; Reid et al., 2013; Shi et al., 2013). Penggunaan komoditas lain yang memiliki tingkat tropik yang lebih rendah juga sudah diterapkan, misalnya dengan menggunakan rumput laut (Troell et al., 1997; Hayasi et al., 2008; Handa et al., 2013; Radiarta et al., 2014a) untuk memanfaatkan ketersediaan nutrien dari KJA ikan laut. Dari hasil penelitian tersebut menunjukkan secara nyata bahwa pertumbuhan rumput laut di sekitar KJA lebih baik. Hasil penelitian Radiarta et al. (2014a) di Teluk Gerupuk menunjukkan bahwa performansi pertumbuhan rumput laut yang terintegrasi dengan keramba ikan laut sangat baik dengan laju pertumbuhan berkisar antara 4.26-4.68\%/hari (Kappaphycus alvarezii varian Maumere) dan berkisar antara 3.90-4.20\%/hari (Kappaphycus alvarezii varian Tambalang). Secara umum melalui sistem budidaya multi-tropik terintegrasi (IMTA) ini, peningkatan produksi rumput laut dapat mencapai $74 \%$ dibandingkan dengan kontrol (sistem monokultur). Chopin et al. (2004 dalam Troell et al., 2009) memperoleh peningkatan produktivitas rumput laut dan kekerangan yang dibudidayakan di dekat KJA ikan laut sebesar masing-masing $46 \%$ dan $50 \%$.

\section{KESIMPULAN}

Kondisi kualitas perairan sangat penting bagi aktivitas budidaya laut. Program pemantauan kualitas air yang dilakukan selama enam bulan (Juni-November 2014) di 13 titik pengamatan sekitar unit IMTA menunjukkan hasil yang masih baik untuk kegiatan budidaya laut. Analisis WQI dengan menggabungkan tiga parameter utama, yang dikenal dengan indeks minimal $\left(\mathrm{WQI}_{\text {min }}\right)$, mengindikasikan bahwa kondisi kualitas perairan masuk dalam kategori sedang-baik. Adanya KJA memberikan dampak pada pengkayaan nutrien perairan di sekitar unit IMTA. Nutrien (amonium, nitrat, dan ortho-fosfat) di sekitar unit IMTA menunjukkan fluktuasi secara spasial dan temporal. Konsentrasi nutrien umumnya tersedia dengan baik pada jarak $60 \mathrm{~m}$ dari KJA. Pemanfaatan WQI dan kondisi nutrien sangat penting untuk mendukung keberlanjutan budidaya laut. Dari hasil penelitian ini dapat memberikan gambaran yang baik tentang kondisi nutrien yang merupakan aspek penting bagi budidaya rumput laut untuk mendukung pertumbuhan dan produktivitas budidayanya, sehingga dapat ditentukan lokasi budidaya rumput laut yang efektif dan efisien.

\section{UCAPAN TERIMA KASIH}

Penulis mengucapkan terima kasih kepada Balai Budidaya Laut (BBL) Lombok di Sekotong atas bantuannya selama kegiatan lapangan. Kami juga mengucapkan terima kasih kepada Gede Sumarthana (pe- nyuluh BBL Lombok) dan pembudidaya ikan di Ekas: Bapak Alimin dan Idin yang telah membantu kelancaran pengumpulan data selama penelitian. Penelitian ini dibiayai oleh DIPA Pusat Penelitian dan Pengembangan Perikanan Budidaya tahun anggaran 2014.

\section{DAFTAR ACUAN}

Angel, D., \& Freeman, S. (2009). Integrated aquaculture (INTAQ) as a tool for an ecosystem approach to the marine farming sector in the Mediterranean Sea. In D. Soto (ed.). Integrated mariculture: a global review. FAO Fisheries and Aquaculture Technical Paper. No. 529. Rome, FAO, p. 133-183.

Anonimous. (2012). PIJAR. Evaluasi kegiatan program 2011 \& rencana kinerja tahun 2012. Pemerintah Provinsi Nusa Tenggara Barat, $71 \mathrm{hlm}$.

Anonimous. (2013). Pembesaran ikan bawal bintang di keramba jaring apung (KJA). Leaflet. Direktorat Usaha Budidaya. Direktorat Jenderal Perikanan Budidaya, $2 \mathrm{hlm}$.

APHA (American Public Health Association). (2005). Standard Methods for the Examination of Water and Wastewater, $21^{\text {st }}$ Edition. American Water Works Association (AWWA)/American Public Works Association/Water Environment Federation. Washington, USA, 1368 pp.

Bakan, G., Ozkoc, B., Tulek, S., \& Cuce, H. (2010). Integrated environmental quality assessment of Kizilirmak River and its coastal environment. Turkish Journal of Fisheries and Aquatic Siences, 10, 453462.

Barrington, K., Chopin, T., \& Robinson, S. (2009). Integrated multi-trophic aquaculture (IMTA) in marine temperate waters. In D. Soto (eds.). Integrated mariculture: a global review. FAO Fisheries and Aquaculture Technical Paper. No. 529. Rome, FAO, p. 746.

Costa-Pierce, B. (2008). An ecosystem approach to marine aquaculture: a global review. In D. Soto, J. Aguilar-Manjarrez and N. Hishamunda (eds). Building an ecosystem approach to aquaculture. FAO Fisheries and Aquaculture Proceedings. No. 14. Rome, FAO, p. 81-155.

Dawes, C.J. (1981). Marine Botany. John Wiley and Sons, Inc. Canada, 628 pp.

Effendi, H. (2003). Telaah Kualitas Air Bagi Pengelolaan Sumberdaya dan Lingkungan Perairan. Kanisius. Yogyakarta, $258 \mathrm{hlm}$.

FAO [Food and Agricultural Organization]. (2010). Aquaculture development 4. Ecosystem approach to aquaculture. FAO Technical Guidelines for Responsible Fisheries. No. 5, Suppl. 4. Rome, FAO. 2010, 53 pp.

Fulazzaky, M.A., Seong, T.W., \& Masirin, M.I.M. (2010). 
Assessment of Water Quality Status for the Selangor River in Malaysia. Water Air Soil Pollut, 205, 63-77.

Handa, A., Forbord, S., Wang, X., Broch, O.J., Dahle, S.W., Storset, T.R., Reitan, K.I., Olsen, Y., \& Skjermo, J. (2013). Seasonal-and depth-dependent growth of cultivated kelp (Saccharina latissima) in close proximity to salmon (Salmo salar) aquaculture in Norway. Aquaculture, 414-415, 191-201.

Hanisak, M.D. (1983). The nitrogen relationships of marine macroalgae. In: EJ Carpenter, DG Capone (eds.). Nitrogen in The Marine Environment. New York. Academic Press, p. 699-730.

Hayasi, L., Yokoya, N.S., Ostini, A.S., Pereira, R.T.L., Braga, E.S., \& Oliveira, E.C. (2008). Nutrients removed by Kappaphycus alvarezii (Rhodophyta, Solieriaceae) in integrated cultivation with fishes in re-circulating water. Aquaculture, 277, 185-191.

Holmer, M., Black, K., Duarte, C.M., Marba, N., \& Karakasis, I. (2008). Aquaculture in the ecosystem. Springer Science and Business Media B.V., $326 \mathrm{pp}$.

Johnson, K., \& J. McChow. (2001). Using ArcGIS spatial analysis. Environmental Systems Research Institute (ESRI), Inc, USA, 236 pp.

KKP [Kementerian Kelautan dan Perikanan]. (2014). Blue economy: pembangunan kelautan dan perikanan berkelanjutan. Kementerian Kelautan dan Perikanan, $240 \mathrm{hlm}$.

KLH [Kementerian Lingkungan Hidup]. (2004). Keputusan Menteri Negara Kependudukan dan Lingkungan Hidup No. 51 tahun 2004, tanggal 8 April 2004 tentang baku mutu air laut. Kementerian Lingkungan Hidup. Jakarta, 11 hlm.

Kotiya, A.S., Gunalan, B., Parmar, H., Jaikumar, M., Tushar, D., Jitesh, S.B., \& Makwana, N.P. (2011). Growth comparison of the seaweed Kappaphycus alvarezii in nine different coastal areas of Gujarat coast, India. Advances in Applied Science Research, 2(3), 99-106.

Liu, Y., Saitoh, S-I., Radiarta, I N., Isada, T., Hirawake, T., Mizuta, H., \& Yasui, H. (2013). Improvement of an aquaculture site-selection model for Japanese kelp (Saccharina japonica) in southern Hokkaido, Japan: an application for the impacts of climate events. ICES Journal of Marine Science, doi:10.1093/icesjms/fst108.

Lumb, A., Sharma, T.C., \& Bibeault, J-F. (2011). A review of genesis and evolution of water quality index (WQI) and some future directions. Water Qual. Expo Health, 3, 11-24.

Manoppo, A.K.S., Emiyati, Budhiman, S., \& Hasyim, B. (2014). Ekstraksi informasi keterlindungan perairan dari data penginderaan jauh untuk ke- sesuaian budidaya rumput laut di Pulau Lombok. Prosiding Seminar Nasional Penginderaan Jauh. Jakarta, hlm. 598-609.

Neori, A., Spigel, M., \& Ben-Ezra, D. (2000). A sustainable integrated system for culture of fish, seaweed and abalone. Aquaculture, 186, 297-291.

Nontji, A. (2008). Plankton laut. Pusat Penelitian Oseanografi. Lembaga Ilmu Pengetahuan Indonesia (LIPI). LIPI Press, $331 \mathrm{hlm}$.

Nontji, A. (1993). Laut Nusantara. Penerbit Djambatan, $362 \mathrm{hlm}$.

Parello, S., Tomassetti, P., Manzueto, L., Finoia, M.G., Persia, E., Mercatali, I., \& Stipa, P. (2005). The influence of marine cages on the sediment chemistry in the Western Mediterranean Sea. Aquaculture, 249, 145-158.

Parenrengi, A., Rachmansyah, \& Suryati, E. (2011). Budidaya Rumput Laut Penghasil Karaginan (Karaginofit). Edisi Revisi. Balai Riset Perikanan Budidaya Air Payau, Badan Penelitian dan Pengembangan Kelautan dan Perikanan, Kementerian Kelautan dan Perikanan, Jakarta, 54 hlm.

Pesce, S.F., \& Wunderlin, D.A. (2000). Use of water quality indices to verify the impact of Co' rdoba city (Argentina) on Suquia River. Water Res., 34, 2915-2926.

Pong-Masak, P.R., Parenrengi, A., Tjaronge, M., \& Rusman. (2012). Protokol seleksi varietas bibit unggul rumput laut. Balai Penelitian dan Pengembangan Budidaya Air Payau, Pusat Penelitian dan Pengembangan Perikanan Budidaya, Badan Penelitian dan Pengembangan Kelautan dan Perikanan, Kementerian Kelautan dan Perikanan, Jakarta, 27 hlm.

Poonam, T., Tanushree, B., \& Sukalyan, C. (2013). Water quality indices-important tools for water quality assessment: a review. International Journal of Advances in Chemistry, 1(1), 15-28.

Priyambodo, B., Styabudi, H., Garnawansyah, G., Supriyanto, A., \& Yana, A. (2012). Petunjuk teknis budidaya kerang abalone. Kementerian Kelautan dan Perikanan. Direktorat Jenderal Perikanan Budidaya. Balai Budidaya Laut Lombok, 36 hlm.

Rachmansyah, Usman, Pongsapan, D.S. (2003). Pendugaan beban limbah dari budidaya bandeng dalam keramba jaring apung di laut. Jurnal Penelitian Perikanan Indonesia edisi Akuakultur, 9(2), 65-76.

Radiarta, I N., Wardoyo, S.E., Priono, B., \& Praseno, O. (2003). Aplikasi sistem informasi geografis untuk penentuan lokasi pengembangan budidaya ikan laut di Teluk Ekas, Nusa Tenggara Barat.Jurnal Penelitian Perikanan Indonesia edisi Akuakultur, 9(1), 67-80.

Radiarta, I N., Erlania, \& Sugama, K. (2014a). Budidaya 
rumput laut, Kappaphycus alvarezii secara terintegrasi dengan ikan kerapu di Teluk Gerupuk Kabupaten Lombok Tengah, Nusa Tenggara Barat. Jurnal Riset Akuakultur, 9(1), 125-134.

Radiarta, I N., Erlania, Johan, O., \& Sugama, K. (2014b). Kajian pengembangan sistem budidaya laut terintegrasi berbasis IMTA (Integrated Multi-Trophic Aquaculture). Laporan Teknis Hasil penelitian. Pusat Penelitian dan Pengembangan Perikanan Budidaya. Tidak dipublikasi, $30 \mathrm{hlm}$.

Reid, G.K., Chopin, T., Robinson, S.M.C., Azevedo, P., Quinton, M., \& Belyea, E. (2013). Weight ratios of the kelps, Alaria esculenta and Saccharina latissima, required to sequester dissolved inorganic nutrients and supply oxygen for Atlantic salmon, Salmo salar, in Integrated Multi-Trophic Aquaculture systems. Aquaculture, 508-409, 34-46.

Sanderson, J.C., Cromey, C.J., Dring, M.J., \& Kelly, M.S. (2008). Distribution of nutrients for seaweed cultuvation around salmon cages at farm sites in north-west Scotland. Aquaculture, 278, 60-68.

SimÕes, F.D., Moreira, A.B., Bisinoti, M.C., Gimenez, S.M.N., \& Yabe, M.J.S. (2008). Water quality index as a simple indicator of aquaculture effects on aquatic bodies. Ecological Indicators, 8, 476-484.

Shi, H., Zheng, W., Zhang, X., Zhu, M., \& Ding, D. (2013). Ecological-economic assessment of monoculture and integrated multi-trophic aquaculture in Sanggou Bay of China. Aquaculture, 410-411, 172-178.

Soto, D., Aguilar-Manjarrez, J., Brugère, C., Angel, D., Bailey, C., Black, K., Edwards, P., Costa-Pierce, B., Chopin, T., Deudero, S., Freeman, S., Hambrey, J., Hishamunda, N., Knowler, D., Silvert, W., Marba, N., Mathe, S., Norambuena, R., Simard, F., Tett, P., Troell, M., \& Wainberg, A. (2008). Applying an ecosystem-based approach to aquaculture: principles, scales and some management measures. In D. Soto, J. Aguilar-Manjarrez and N. Hishamunda (eds). Building an ecosystem approach to aquaculture. FAO/Universitat de les Illes Balears Expert Workshop. 7-11 May 2007, Palma de Mallorca, Spain. FAO Fisheries and Aquaculture Proceedings. No. 14. Rome, FAO, p. 15-35.

Soto, D. (ed.). 2009. Integrated mariculture: a global review. FAO Fisheries and Aquaculture Technical Paper. No. 529. Rome, FAO, 183 pp.

Stickney, R.R. (2009). Aquaculture: an introductory text, $2^{\text {nd }}$ Edition. Cambridge University Press, 304 pp.

Troell, M., Halling, C., Nilsson, A., Buschmann, A.H., Kautsky, N., \& Kautsky, L. (1997). Integrated marine cultivation of Gracilaria chilensis (Gracilariales, Rhodophyta) and salmon cages for reduced environmental impact and increased economic output. Aquaculture, 156, 45-61.

Troell, M., A. Joyce, T. Chopin, A. Neoru, A.H. Bushmann, \& J-G. Fang. (2009). Ecological engineering in aquaculture-Potential for integrated multi-trophic aquaculture (IMTA) in marine offshore systems. Aquaculture, 297, 1-9.

Troell, M. (2009). Integrated marine and brackishwater aquaculture in tropical regions: research, implementation and prospects. In D. Soto (ed.). Integrated mariculture: a global review. FAO Fisheries and Aquaculture Technical Paper. No. 529. Rome, FAO, p. 47-131.

Wang, X., Olsen, L.M., Reitan, K.I., \& Olsen, Y. (2012). Discharge of nutrient wastes from salmon farms: environmental effects, and potential for integrated multi-tropic aquaculture. Aquaculture Environment Interaction, 2, 267-283.

Yuniarsih, E., Nirmala, K., \& Radiarta, I N. (2014). Tingkat penyerapan nitrogen dan fosfor pada budidaya rumput laut berbasis IMTA (integrated multitrophic aquaculture) di Teluk Gerupuk, Lombok Tengah, Nusa Tenggara Barat. Jurnal Riset Akuakultur, 9(3), 487-501. 